\title{
India's reactors run into trouble
}

\section{New Delhi}

INDIA's RAPP-1 nuclear-power reactor in Rajasthan state seems set to gain an unenviable world record as the first reactor to be prematurely retired. It has been in service for just eight years.

The Canadian-built $230 \mathrm{MW}$ (E) pressurized heavy-water reactor has been out of action since March 1982 following detection of a crack in the end-shield of the reactor vessel. A four-year battle. using remote-controlled tools, failed to plug the leak in a highly radioactive and inaccessible area which, according to Dr M.R. Srinivasan, chairman of the nuclear power board, "has become embrittled by radiation". The only options now are an expensive operation to replace the end-shield after a long wait to "cool" the reactor, or a permanent close down of the $£ 110$ million reactor. According to nuclear engineers, closing down for good will be more economical.

More bothersome to India is the problem that has crippled the 100 -MW (thermal) Dhruva reactor in Trombay, a key facility for producing plutonium. The high flux, $£ 60$ million reactor which went critical last August, was expected to generate about 60 kilograms of plutonium annually. But Dhruva has dashed India's hopes of producing and stockpiling plutonium because a design flaw prevents the reactor operating above $20 \mathrm{MW}$.

Dhruva, which uses natural uranium as fuel and heavy water as coolant and moderator, is a bigger and improved version of the Canadian-built 40-MW (thermal) reactor Cirus which supplied the plutonium for India's nuclear test in 1974. One major difference is that being a production reactor, Dhruva's fuel pellets are clad with aluminium (instead of the usual aluminium-zirconium alloy) to make reprocessing of plutonium easier. It is not known if the choice of aluminium for cladding and coolant tubes was a mistake. According to Dr P.K. Iyengar, director of the Bhabha Atomic Research Centre (BARC), Dhruva could not be operated at high power levels because of excessive vibration of the coolant tubes when heavy water was pumped through them under pressure. The vibrations could lead to rupture of the fuel rods inside the coolant tubes which would contaminate the coollant with fission products.

BARC has been trying to solve the problem for the past eight months and has now decided to dampen the vibrations by placing clamps at intervals along the fuel rods. According to lyengar, simulated runs after partially loading the reactor with modified fuel bundles have shown satisfactory performance. But the question of whether the clamps will provide a

permanent solution will be answered only in actual operation. Similar vibration problems also cropped up in the Superphénix reactor in France according to Iyengar, who hopes that Dhruva can begin operation in a month.

Recommissioning of Dhruva is vital for India's goal of accumulating sufficient stocks of plutonium to fuel its breeder reactors in the second phase of its power programme. The 25-year-old Cirus, the only other plutonium-producing research reactor, is operating at half its capacity and is due for decommissioning. India has the means to reprocess plutonium from spent fuel, but international agreements

\section{Environmental protection}

\section{Ice-minus test stopped yet again}

\section{Washington}

THE first field test of bacteria that have been genetically engineered to protect plants against frost damage will not, after all, take place this year. The University of California, which is proposing the test, last month agreed with opponents that it would re-examine safety issues before going ahead. Because the test cannot be performed during the winter months, it is now unlikely to take place before next spring.

The test was first proposed by Steven Lindow of the University's Berkeley campus in 1982. Lindow plans to spray potato plants with a genetically altered strain of Pseudomonas syringae that has had removed the gene responsible for producing an ice-nucleating protein. Because the protein in naturally occurring $P$. syringae acts as a focus for ice crystal formation on host plants, Lindow hopes that the engineered form will reduce frost damage.

Lindow's experiment has already been the subject of environmental impact assessments and formal approval by two federal agencies, the National Institutes of Health and the Environmental Protection Agency. But earlier this month, local groups, together with Jeremy Rifkin's Foundation on Economic Trends, obtained a temporary restraining order against the university on the grounds that it may not have met the requirement of Californian law for a local environmental impact report if any significant impact is thought plausible.

The out-of-court agreement now reached obliges the university to review all the safety evidence once again and to decide within 30 days if a local impact report is indeed needed. But the plaintiffs have also agreed to provide any new evidence they want taken into account, and if they disagree with prevent it from doing so at four of its six power reactors. The United States has not permitted India to reprocess fuel from the two American-built reactors in Tarapur.

India has been reprocessing the fuel from the two 23()-MW reactors in Rajasthan. RAPP-1 and RAPP-2, but an agreement with the Soviet Union (which supplied heavy water) forbids India from diverting the processed plutonium to any unrestricted facility. In a major move to overcome this restraint, BARC has now decided to burn the plutonium along with thorium in RAPP-2 itself. By conserving natural uranium, which is scarce in India, BARC says its strategy will help use the plutonium. India is free to use the plutonium processed from its power reactors in Madras but reprocessing of fuel has not yet begun.

K.S. Jayaraman

the university's assessment have only a further 30 days in which to sue. Lindow says he hopes that the deal will mean that there will be no more last-minute hitches. Numerous and expensive preparations for the experiment had to be abandoned when the temporary restraining order was issued on 4 August, just 2 days before the test was due to start. Tim Beardsley

\section{Sun shines on UN's} Kabul venture

UNITED Nations funds are helping to set up a new research and development centre for solar energy in the Afghan capital of Kabul, according to the official news agency Bakhtar. The foundation stone was laid on 5 August and construction is due to be completed by 1990 ,

Facilities are to include production workshops, laboratories, showrooms, small water stations, greenhouses, small animal husbandry farms, poultry rearing and a "typical biogas plant". Equipping the centre, and the training of "technical cadres" is expected to cost some US\$1.2 million. When completed the centre should meet the "energy needs of the people for lighting and heating of buildings, water supply and cooking".

This major $\mathrm{UN}$ investment represents a new phase in Afghanistan's development. Until the socialist "Sowr revolution", the principal source of foreign investment was the United States which, for example, had plans to develop at Kandahar the largest airport in Asia. Since the Soviet "fraternal intervention" of December 1979, the main source of aid has been the Soviet Union, which has provided the funds for facilities ranging from primary schools and hospitals to a sophisticated new broadcasting centre.

Vera Rich 